\title{
HUBUNGAN ANTARA ORIENTASI MASA DEPAN AREA PEKERJAAN DENGAN MOTIVASI BERPRESTASI PADA MAHASISWA PSIKOLOGI ANGKATAN 2001 UIN SGD BANDUNG
}

\author{
Nisa Hermawati \\ UIN Sunan Gunung Djati Bandung, Jl. A.H. Nasution 105 \\ e-mail: yasminesyafa@yahoo.co.id
}

\begin{abstract}
This research aimed to obtaining empirical data on relationship between future orientations of working area with achievement motivation among student of psychology faculty UIN SGD Bandung class of 2001. Research design was a correlational study. The result shown there was a positive correlations between future orientation of working area and achievement motivation. It means that student who optimism on future orientation of working area so their achievement motivation increasing, in reverse, if student future orientation working area pessimism so their achievement motivation decreasing.
\end{abstract}

Keywords : Planning, achievement motivation, future orientation of working area

\begin{abstract}
Abstrak
Tujuan penelitian ini adalah untuk memperoleh data empiris mengenai hubungan antara orientasi masa depan area pekerjaan dengan motivasi berprestasi pada mahasiswa Psikologi angkatan 2001 UIN SGD Bandung. Pendekatan yang digunakan adalah kuantitatif korelasional. Hasil korelasi menunjukkan bahwa terdapat hubungan positif antara orientasi masa depan area pekerjaan dengan motivasi berprestasi pada mahasiswa Psikologi angkatan 2001 UIN SGD Bandung. Artinya jika orientasi masa depan area pekerjaannya pesimis maka motivasi berprestasinya akan rendah, sebaliknya jika orientasi masa depan area pekerjannya optimis maka motivasi berprestasinya akan tinggi.
\end{abstract}

Kata kunci : perencanaan, motivasi berprestasi, orientasi masa depan area pekerjaan

\section{PENDAHULUAN}

Menghadapi perkembangan zaman yang semakin cepat, Indonesia menapaki suatu rentang yang menentukan di dalam keseluruhan perjuangan bangsa, yaitu proses tinggal landas menuju masyarakat yang maju dan mandiri. Oleh karena itu, untuk menyongsong era persaingan dunia yang semakin tajam, bangsa kita dituntut untuk mencapai keunggulan menuju tingkat produktivitas nasional yang tinggi. Agar memenangkan persaingan tersebut, kita harus menguasai ilmu pengetahuan dan teknologi serta keterampilan. Upaya yang harus ditempuh untuk menciptakan generasi bangsa yang menguasai ilmu pengetahuan dan teknologi, adalah dengan pengembangan sumber daya manusia melalui pendidikan yang menekankan pada penguasaan ilmu pengetahuan dan teknologi.

Sejalan dengan itu persaingan global memunculkan kualifikasi dan tuntutan yang sangat beragam. Kemampuan dan keterampilan individu menjadi sangat penting dan berharga. Hanya individu-individu yang berkualitaslah yang mampu unggul dalam persaingan tersebut. Kenyataan ini tentunya perlu diantisipasi sejak dini, dengan kata lain perlu persiapan sejak awal dalam menghadapi persaingan tersebut, baik untuk saat ini maupun di masa yang akan datang.

Sebagai negara berkembang, bangsa Indonesia tentunya harus memandang secara positif keadaan tersebut. Apalagi bila kita lihat bahwa Negara Indonesia memiliki jumlah penduduk yang cukup besar. Artinya secara nyata bangsa kita 
telah memiliki sumber daya manusia yang cukup banyak secara kuantitas. Oleh karenanya, salah satu upaya yang perlu dila-kukan dalam mengantisipasi masa depan itu adalah dengan meningkatkan pembinaan dan pengembangan sumber daya manusia secara kualitas, yakni melalui jalur pendidikan.

Perguruan tinggi sebagai jenjang pendidikan tertinggi di Indonesia menjadi sarana bagi pencapaian tujuan tersebut. Ini sesuai dengan tujuan perguruan tinggi menurut UU No. 2 tahun 1989 pasal 16 tentang Perguruan Tinggi, yaitu menciptakan manusia yang memiliki kemampuan akademik secara professional sesuai dengan bidangnya masing-masing.

Sebagai mahasiswa, mereka dituntut untuk memiliki tanggung jawab yang besar terutama yang berhubungan dengan penentuan masa depannya sesuai dengan tugas perkembangannya. Mereka harus mulai memikirkan masa depannya dengan membuat rencana-rencana positif untuk kehidupan yang akan datang yang salah satunya adalah masalah pendidikan yang kemudian akan berlanjut pada masalah pekerjaan. Hal itu sejalan dengan ajaran Islam yang senantiasa menuntun umatnya agar memperhatikan atau merencanakan sertiap tindakannya di masa yang akan datang. Sebagaimana disebutkan dalam Al-Qur'an surat Al-Hasyr : 18 yang berbunyi : Hai orang-orang yang beriman, bertaqwalah kepada Allah dan hendaklah setiap diri memperhatikan apa yang telah diperbuatnya untuk hari esok, dan bertaqwalah kepada Allah, sesungguhnya Allah Maha Mengetahui apa yang kamu kerjakan.

Dari ayat tersebut di atas tersirat makna, bahwa jika kita ingin mencapai sesuatu yang kita inginkan di masa yang akan datang, tentunya diperlukan suatu usaha yang sungguh-sungguh. Jika seorang mahasiswa ingin mencapai suatu tujuan yang diharapkan, diperlukan usaha yang direncanakan secara matang.

Hal ini sesuai dengan yang dikatakan oleh Nurmi (1991), bahwa seorang mahasiswa idealnya sudah memiliki gambaran yang jelas tentang orientasi masa depan khususnya dalam area pekerjaan.

Dalam kenyataannya, orientasi masa depan khususnya dalam area pekerjaan pada setiap orang itu berbeda-beda, ada yang optimis dan ada pula yang pesimis. Perbedaaan tersebut dapat dari motivasi, perencanaan dan evaluasi yang dimiliki dalam diri orang tersebut. Hal ini dapat diamati pada mahasiswa psikologi angaktan 2001, yaitu ada mahsiswa yg mengindikasikan orientasi masa depannya optimis, sebaliknya ada pula yang mengindikasikan orientasi masa depannya pesimis.

Diperoleh informasi dari beberapa dosen dan angkatan lain yang ada, bahwa mahasiswa Paikologi angkatan 2001 ini banyak yang mengeluh mengenai masa depannya khususnya yang berkaitan dengan masalah pekerjaan. Selain itu juga, diperoleh informasi dari beberapa mahasiswa Psikologi angkatan 2001 UIN SGD Bandung secara langsung, mereka mengeluh belum dapat memikirkan masa depan mereka khususnya yang berkaitan dengan masalah pekerjaan.

Hal menarik lainnya, selain informasi mengenai masalh masa depan khususnya yang berkaitan dengan pekerjaan, diperoleh juga informasi dari beberapa dosen juga serta mahasiswa angkatan lainnya yang ada, bahwa mahasiswa angkatan 2001 UIN SGD Bandung ini memiliki perbedaan yang sangat ekstrim sekali dibandingkan dengan angkatan lainnya, khususnya yang berkaitan dengan masalah proses belajar selama perkuliahan serta prestasi akademiknya.

Berdasarkan informasi tersebut, peneliti menjadi tertarik untuk mengungkap lebih jelas mengenai fenomena yang sebenarnya terjadi pada mahasiswa Psikologi angkatan 2001 UIN SGD Bandung, dengan melakukan wawancara pada beberapa mahasiswa psikologi angkatan 2001 UIN SGD Bandung. 
Setelah dilakukan wawancara pada 34 orang mahasiswa Psikologi angkatan 2001 ini, sebesar 70,5 \% mahasiswanya mengindikasikan pesimis dalam memikirkan masa depan khususnya dalam area pekerjaan. Mereka memang memandang bahwa karier adalah sebagai sesuatu yang penting, tetapi mereka masih merasa pesimis untuk menentukan dengan pasti minat pekerjaan apa yang akan mereka tempuh dimasa yang akan datang, belum dapat memfokuskan suatu pilihan pekerjaan atau karier yang akan ditempuh, memiliki sedikit keterangan tentang karier atau pekerjaan, belum membuat strategi untuk menghadapi masa depan khususnya yang berkaitan dengan pekerjaan dan tidak merasa yakin dapat merealisasikan rencana-rencana karier atau pekerjaan dimasa yang akan datang.

Selain adanya fenomena kesulitan dalam menentukan pilihan minat pekerjaan dimasa depan yang akan dijalani setelah lulus dari perguruan tinggi nanti. Hal lainnya yang terjadi pada mahasiswa Psikologi angkatan 2001 UIN SGD Bandung, berdasarkan informasi dari pihak jurusan, bahwa yang IPK diatas 2,75 dari 34 jumlah mahasiswa Psikologi angkatan 2001 hanya sebanyak 6 mahasiswa $(17,6 \%)$ saja, sedangkan pada mahasiswa Psikologi angkatan lainnya, yang memperoleh IPK di atas 2,75 rata-rata setengah dari jumlah mahasiswanya.

Berdasarkan atas informasi tersebut peneliti menjadi tertarik untuk mengungkap lebih jelas mengenai fenomena sebenarnya terjadi pada mahasiswa Psikologi angkatan 2001 UIN SGD Bnadung, dengan melakukan wawancara ada beberapa mahasiswa Psikologi angkatan 2001 UIN SGD Bandung.

Setelah melakukan wawancara terhadap 34 orang mahasiswa Psikologi angkatan 2001 UIN SGD Bandung, ternyata sebagian besar mahasiswanya meng-indikasikan motivasi berprestasi yang rendah. Berdasarkan informasi yang diperoleh dari hasil wawancara pada 34 mahasiswa Psikologi angkatan 2001 ini, sekitar 50\% masih ada yang belum mengambil mata kulah sesuai dengan yang disajikan dari pihak jurusan, kurang mempunyai penghayatan waktu yang dinamis, memiliki keuletan yang kurang dalam menyelesaikan tugas yang telah dimulai, kurang mempunyai kemampuan berusaha yang kuat dalam menghadapi suatu tugas, kurang berani memilki resiko, dan pandangan waktu yang belum mengarah pada masa depan.

Seharusnya pada masa usia dewasa awal ini, mahasiswa idealnya sudah mampu menunjukan dirinya sebagai individu yang mandiri. Dalam hal ini, mereka sudah harus memiliki motivasi yang kuat serta mampu memotivasi dirinya untuk dapat berprestasi tinggi. Hal ini sesuai dengan apa yang dikatakan Hurlock (1999: 253), bahwa pada masa dewasa awal ini idealnya harus memiliki motivasi yang kuat untuk menguasai tugas-tugas yang dihadapinya.

Agar mencapai prestasi yang tinggi, maka salah satu faktor penting dalam proses belajar adalah motivasi berprestasi, karena motivasi berprestasi merupakan faktor yang menjunjung pencapaian akhir belajar yang optimal. Hal itu sebagai mana yang dikemukakan oleh Wingkel (2004) bahwa salah satu faktor yang penting dalam kegiatan belajar adalah motivasi berprestasi,yaitu daya penggerak dalam diri seorang untuk mencapai prestasi belajar setinggi mungkin demi penghargaan kepada dirinya sendiri, sehingga motivasi berprestasi sering dianggap sebagai salah satu faktor penting yang berpengaruh terhadap prestasi belajar.

Adanya fenomena yang mengindikasikan pesimisnya orientasi masa depan khususnya dalam area pekerjaan dan rendahnya motivasi berprestasi pada mahasiswa Psikologi angkatan 2001 UIN SGD Bandung ini, menimbulkan satu pertanyaan apakah kedua hal tersebut saling berkaitan? Oleh karena itu peneliti tertarik untuk mengetahui lebih lanjut mengenai keeratan hubungan antara orientasi masa depan area pekerjaan 


\section{dengan motivasi berprestasi pada mahasiswa Psikologi angkatan 2001 UIN SGD Bandung.}

\section{TINJAUAN TEORITIS}

\section{Pengertian Orientasi Masa Depan Area} Pekerjaan

Dalam diri setiap individu terdapat skema kognitif. Skema kognitif ini merupakan gambaran yang dimiliki oleh seseorang tentang dirinya dan lingkungannya. Adapun fungsi dari skema kognitif itu sendiri yakni agar seseorang mampu menghadapi kemungkinan perubahan dari berbagai aktivitas yang terjadi di masa depan. Skema berisikan perkembangan sepanjang rentang kehidupan yang diantisipasi, pengetahuan konteks, konsep diri dan attributional style (Nurmi, 1989).

Berdasarkan schemata yang dihasilkan, individu akan membentuk harapan baru yang ingin diwujudkan dalam kehidupan dimasa depan. Selain itu juga, individu mengantisipasi kejadian yang akan terjadi dimasa depan dan memberi arti tersendiri bagi masing-masing kejadian tersebut. Selanjutnya individu juga mampu memberikan penilaian atau evaluasi mengenai kejadian dan masalah tinghkah laku yangdiharapkan di masa depan. Pada akhirnya, terbentuklah orientasi individu di masa depannya.

Untuk dapat memikirkan dan merencanakan masa depannya, seseorang diharapkan mempunyai gambaran tentang dirinya dalam konteks masa depan yang istilah Nurmi (1989 : 34) dinamakan orientasi masa depan. Gambaran ini akan membantu individu dalam mengarahkan dirinya untuk mencapai perubahanperubahan sistematis agar dapat tercapai apa yang diinginkannnya.

Nurmi (1989 : 23) mengemukakan bahwa orientasi masa depan adalah bagaimana seseorang memandang masa depannya menyangkut harapan-harapan, tujuan standar, perencanaan dan strategi pencapaian tujuan.

Salah satu orientasi masa depan yang pada masa dewasa awal adalah dalam area pekerjaan. Hal tersebut sesuai dengan salah satu tugas perkembangan individu yang berada pada masa dewasa awal yakni mendapatkan pekerjaan agar dirinya dapat dianggap sebagai individu yang mandiri (Hurlock, 1999 : 252).

Dalam mengarahkan diri ke masa depannya menurut Nurmi (1989 : 16), bahwa seseorang yang berada pada masa dewasa awal akan mengalami proses dalam diri yang meliputi tiga tahap. Pertama adalah motivasi, berkaitan dengan memikirkan minat perkerjaan dan menetapkan minat pekerjan di masa depan. Kedua adalah perencanaan, berkaitan dengan membuat rencana tentang mem-buat pekerjaan, melakukan eksplorasi informasi yang berkaitan dengan pekerjaan dan membuat strategi-strategi untuk dapat merealisasikan rencana-rencana yang telah disusun. Ketiga adalah evaluasi, berkaitan dengan melakukan evaluasi terhadap kesempatan untuk dapat memproleh pekerjaan, melakukan evaluasi terhadap faktor yang menyebabkan tercapainya pekerjaan di masa depan dan melakukan evaluasi terhadap pernyataan emosi atas keberhasilan atau kegagalan dalam mendapatkan pekerjaan dimas depan.

Berdasarkan atas penjelasan mengenai schemata kognitif sebelumnya, melalui schemata kognitif inilah seseorang akan memberikan penilaian terhadap ketiga proses orientasi masa depan yakni motivasi, perencanaan dan evalusi. Orientasi masa depan ini dengan istilah optimis dan pesimis. Orientasi masa depan yang optimis adalah gambaran individu tentang masa depn yang sudah jelas yang terkait dengan motivasi, perencanaan dan evaluasinya, sedangkan orientasi masa depan yang pesimis adalah gambaran diri individu tentang masa depan yang belum jelas yang berkaitan dengan motivasi, perencanaan dan evaluasinya. Individu yang orientasi masa depannya optimis khusunya dala area pekerjaan akan mempersiapkan segala sesuatu yang terkait dengan realisasi rencana-rencana masa depannya. Salah satunya dapat diwujudkan 
melalui prestasi, karena prestasi biasanya dijadikan satu kriteria dalam proses seleksi untuk mendapatkan pekerjaan di masa depan. Agar prestasi tinggi maka salah satunya perlu motivasi berprestasi. Dengan kata lain, jika seseorang itu memiliki orientasi masa depan khususnya dalam area pekerjaannya optimis maka orang tersebut akan terdorong untuk memiliki motivasi berprestasi yang tinggi. Sebaliknya, jika orientasi masa depan khususnya dalam area pekerjaan pesimis maka orang tersebut menjadi tidak terdorong untuk memiliki motivasi berprestasiyang tinggi (rendah).

Kesiapan yang dapat diwujudkan oleh mahasiswa dalam menghadapi masa depannya, adalah dengan memiliki motivasi yang tinggi sehingga pada akhirnya dapat memperjelas tujuan yang ingin dicapai di masa mendatang khususnya yang berkaitan dengan pekerjaan.

\section{Pengertian Motivasi Berprestasi}

Motivasi berprestsi menurut Herman (1967) adalah kecenderungan untuk berbuat melebihi atau mengungguli orang lain, baik ditinjau dari sudut orang lain maupun dari sudut diri sendiri. Arti melebihi orang lain disini, berarti bahwa tanggung jawab pribadi (diri sendiri) lebih penting dari pada orang lain jadi makna kunci bagi motivasi brprestasi adalah tanggunng jawab sendiri.

Motivasi berprestasi inilah yang mendorong mahasiswa untuk bertanggung jawab secara mandiri dalam mengembangkan drinya, berprakarsa diri, memanfaatkan sebesar-besarnya berbagai kemampuan yang ada dalam dirinya dan memanfaatkan berbagai kesempatan yang ada dalam lingkungan, karena pada dasarnya setiap individu merupakan penentu bagi tingkah lakunya sendiri.

Hal ini sesuai dengan apa yang diungkapkan oleh Herman (1967), bahwa salah satu ciri individu yang mempunyai motivasi berprestasi tinggi adalah pandangan mengenai waktu yang diarahkan ke masa depan.
Pemikiran terhadap masa depan ini sangat dibutuhkan oleh para mahasiswa dalam motivasi berprestasinya. Begitu juga sebaliknya, bahwa motivasi berprestasi sangat diperlukan untuk mengarahkan seseorang menuju masa depannya.

Dengan demikian, bahwa dengan adanya pandangan yang lebih diarahkan ke masa depan, seseorang itu dapat lebih terdorong untuk memiliki motivasi berprestasi yang tinggi. Sebaliknya, seseorang yang memiliki motivasi berprestasi yang tinggi dapat mendorong seseorang menjadi lebih optimis dalam orientasi masa depannya khususnya dalam area pekerjaan.

Berdasarkan atas kerangka pemikiran diatas, penulis membuat suatu hipotesis penelitian : "Terdapat korelasi yang positif antara orientasi masa depan khususnya dalam area pekerjaan dengan motivasi berprestasi pada mahasiswa psikologi angkatan 2001 UIN SGD Bandung“.

\section{Metodologi Penelitian}

Penelitian ini bertujuan untuk melihat hubungan antara orientasi masa depan area pekerjaan dengan motivasi berprestasi, sehingga rancangan penelitian yang digunakan pendekatan non-eksperimental dengan menggunakan metode korelasional, yaitu bertujuan untuk melihat sejauh mana korelasi antar dua variable tersebut.

\section{Variabel Penelitian}

Variable-variabel yang terlibat dalam penelitian ini sebagai berikut:

- Variable pertama $\left(\mathrm{X}_{1}\right)$ : orientasi masa depan area pekerjaan

- Variable kedua $\left(\mathrm{X}_{2}\right)$ : motivasi bekerja

Sedangkan secara operasional Orientasi masa depan area pekerjaan adalah seberapa sesuai diri subjek dengan karakteristik yang memiliki motivasi, melakukan perencanaan dan melakukan evaluasi terhadap realisasi masa depannya.

Motivasi berprestasi adalah sebarapa besar frekuensi dan intensitas tingkah laku seseorang untuk dapat melebihi atau melebihi untuk menungguli yang lainnya dalam hal berprestasi, baik ditinjau dari 
sudut orang lain juga dari dirinya sendiri, yang dapat diukur dari indikasi-indikasi: memilih tugas dengan tingkat kesulitan sedang, lebih menyukai resiko kecil apabila hasil tindakan lebih ditentukan faktor kebetulan, mencapai taraf keahlian tinggi, memiliki keuletan mengadapi tugas, pandangan waktu lebih diarahkan pada masa depan, mempunyai kemampuan berusaha besar, mempunyai penghayatan waktu yang dinamis, ada pengakuan atas hasil yang dicapai dalam prestasinya, memilih keahlian dalam menghadapi tugas dan menghasilkan prestasi yang lebih baik dalam situasi yang berinsentif. Tinggirendahnya motivasi berprestasi mahasiswa Psikologi angkatan 2001 UIN SGD Bandung ditunjukan oleh total skor subjek pada Skala PMT.

\section{Teknik Pengumpulan Data}

Teknik pengumpulan data yang dipilih dalam penelitian ini adalah dengan menggunakan metode kuesioner, yaitu merupakan daftar pertanyaan yang diberikan kepada orang lain dengan maksud agar orang yang diberi pertanyaan tersebut tersedia memberikan respons sesuai dengan permintaan pengguna (Azwar, 2002: 6). Adapun teknik pelaksanaanya, subjek diberikan sebuah pertanyaan, kemudian subjek diminta untuk mengisi pertanyataan-pernyataan sesuai dengan keadaan subjek yang disajikan oleh peneliti.

\section{Instrumen Pengumpulan Data}

Adapun jenis instrumen atau alat ukur yang dipilih dalam penelitian ini berupa skala, yaitu Skala Orientasi Masa Depan Area Pekerjaan dari Nurmi yang telah diakomodasi itemnya oleh penelitiannya (untuk menjamin variable kesatu) dan skala motivasi berprestasi dari Herman yang telah dimodifikasi alternatif jawabannya oleh peneliti yang disebut Prestative Motivatie (untuk menjamin variable kedua).

\section{HASIL DAN PEMBAHASAN}

\section{Hasil Perhitungan Dan Pengujian Hipotesis Statistik}

Untuk mengetahui seberapa erat hubungan antara orientasi mas depan area pekerjaan dengan motivasi berprestasi pada mahasiswa Psikologi angkatan 2001 UIN SGD Bandung, dilakukan perhitungan statistik dengan menggunakan metode uji korelasi Rank Spearman, karena data yang diperoleh berupa data ordinal. Adapun hipotesis statistik yang diuji adalah sebagai berikut:

$$
\begin{aligned}
& \text { Ho : } \mathrm{r}_{\mathrm{s}} 0 \text { : Tidak terdapat } \\
& \text { hubungan positif antara orientasi } \\
& \text { masa depan area pekerjan dengan } \\
& \text { motivasi berprestasi } \\
& \mathrm{H}_{1}: \mathrm{r}_{\mathrm{s}}>0: \text { Terdapat hubungan } \\
& \text { positif antara orientasi masa depan } \\
& \text { area pekerjaan dengan motivasi } \\
& \text { berprestasi }
\end{aligned}
$$

Untuk menguji hipotesis tersebut, telah dilakukan uji korelasi Rank Spearman .

Berdasarkan hasil perhitungan, diperoleh kesimpulan bahwa Ho yang diajukan ditolak sehingga $\mathrm{H}_{1}$ diterima. Koefisien korelasi yang diperoleh sebesar $\mathrm{r}_{\mathrm{s}}=0,770$ dengan $\mathrm{T}_{\text {hit }} 6,8222>\mathrm{T}_{\text {tab }}$ 1,697. Menurut tabel Guilford nilai ini termasuk ke dalam kriteria derajat korelasi tinggi. Hal ini menunjukan bahwa terdapat hubungan positif antara orientasi masa depan area pekerjaan dengan motivasi berprestasi pada mahasiswa Psikologi angkatan 2001 UIN SGD Bandung. Artinya jika mahasiswa Psikologi angkatan 2001 UIN SGD Bandung pesimis orientasi masa depan area pekerjaannya maka motivasi berprestasinya akan rendah, sebaliknya jika orientasi masa depan area pekerjaannya optimis maka motivasi berprestasinya akan tinggi. 


\section{SIMPULAN}

Berdasarkan hasil pengolahan data dan pembahasan serta pengujian hipotesis yang dilakukan dengan menggunakan metode statistik, maka dari penelitian ini dapat disimpulkan sebagai berikut :

1. Bahwa terapat hubungan positif antara orientasi masa depan area pekerjaan dengan motivasi berprestasi pada mahasiswa Psikologi angkatan 2001 UIN SGD Bandung. Artinya jika orientasi masa depan area pekerjaannya pesimis maka motivasi berprestasinya akan rendah, sebaliknya jika orientasi masa depan area pekerjannya optimis maka motivasi berprestasinya akan tinggi.

2. Berdasarkan perhitungan statistik diperoleh bahwa orientasi masa depan area pekerjaan aspek motivasi, perencanaan dan evaluasi memiliki hubungan dengan motivasi berprestasi pada mahasiswa Psikologi angkatan 2001 UIN SGD Bandung. Hal ini berarti terdapat hubungan positif. Artinya tidak terdapat perbedaan yang signifikan diantara ketiga aspek tersebut. Dengan demikian, ketiga aspek tersebut masing-masing berhubungan erat dengan motivasi berprestasi mahasiswa Psikologi Saran angkatan 2001 UIN SGD Bandung.

Setelah memperhatikan data yang diperoleh dari hasil penelitian, bahwa orientasi masa depan area pekerjaan mempunyai hubungan yang erat dengan motivasi berprestasi pada mahasiswa Psikologi angkatan 2001 UIN SGD Bandung, maka ada beberapa hal yang dapat dijadikan sebagai bahan pertimbangan, yaitu :

\section{- Saran bagi mahasiswa Psikologi UIN SGD Bandung :}

1. Mengingat hasil yang diperoleh bahwa adanya hubungan positif antara orientasi masa depan area pekerjaan dengan motivasi berprestasi, bagi seluruh mahasiswa
Psikologi UIN SGD Bandung agar dapat mempersiapkan diri dari sejak awal apa yang ingin mereka capai di masa depan khususnya yang berkaitan dengan masalah karir atau pekerjaan yang ingin mereka raih di masa depan setelah keluar dari perguruan tinggi nanti (dengan kata lain, mengembangkan orientasi masa depan area pekerjaannya yang optimis). Dengan adanya keoptimisan terhadap masa depannya mahasiswa menjadi memiliki motivasi berprestasi yang tinggi selama perkuliahan berlangsung.

2. Mahasiswa diharapkan mengenali potensi diri dengan mengetahui kelebihan dan kekurangan, dapat menerima kelebihan dan menerima kekurangan serta mampu mengembangkan kelebihan dan mengatasi kekurangan, merupakan salah satu antisipasi yang dapat dilakukan agar mahasiswa memiliki gambaran yang jelas mengenai minat dan bakat apa yang mereka miliki, sehingga membantu mereka untuk menghadapi masa depan khususnya yang berkaitan dengan masalah karir atau pekerjaan.

3. Mahasiswa diharapkan dapat menetapkan goal yakni dengan mempunyai tujuan dalam perkuliahan dan juga mampu merumuskan strategi-strategi apa yang dapat dilakukan untuk mencapai tujuan yang diinginkan khususnya yang berkaitan dengan terealisasinya karir dan pekerjaan di masa depan, dengan cara membuat peramalan yang efektif agar dapat mengatasi hambatan yang nantinya akan dihadapi.

4. Untuk dapat meningkatkan motivasi berpretasi, mahasiswa dapat melakukan "time management", yakni mengatur waktu seefisien da seefektif mungkin dengan membuat program kegiatan jangka pendek 
dan jangka panjang dengan cara mengidentifikasi faktor internal, sehingga dengan adanya program yang dibuat, mahasiswa dapat terdorong untuk memiliki motivasi berprestasi tinggi karena mereka memiliki tanggung jawab yang harus dipikul demi tercapainya progra yang telah disusun.

\section{- Saran bagi pihak jurusan :}

1. Bagi pihak jurusan diharapkan menginformasikan berbagai macam pekerjaan, membantu para mahasiswa untuk mengetahui serta mene-tapkan minat pekerjaan yang diminati dari sejak awal, hal ini dapat dilakukan dengan melibatkan peran psikolog dengan dibukanya bimbingan konseling tentang pekerjaan (bimbingan vocational), atau juga dengan peran model srjana Psikologi. Selain itu, dapat juga dilakukan training yang berkaitan dengan orientasi masa depan khususnya area pekerjaan dengan motivasi berprestasi pada awal perjumpaan bagi mahasiswa baru. Hal ini dilakukan dengan tujuan agar mahasiswa dapat mengantisipasi masa depannya, khususnya yang berkaitan dengan pekerjaan, sehingga para mahasiswa dapat mempersiapkan dirinya selama proses perkuliahan untuk menghadapi masa depannya, salah satunya yakni dengan memiliki motivasi berprestasi yang tinggi.

2. Agar mahasiswa dapat mengevaluasi sejauh mana kesempatan yang dimiliki untuk dapat merealisasikan rencana pekerjaannya di masa depan, maka bagi pihak jurusan, terutama biro Psikologi dapat melibatkan mahasiswa sebagai pelaksana dalam Event Organizer (EO) atau juga dlibatkan dalam proyek atau melakukan stage (magang) di biro Psikologi, sehingga dari peng-alaman atau kesempatan untuk mencoba yang diberikan pihak jurusan kepada mahasiswa tersebut, secara tidak langsung mereka dapat melakukan evaluasi terhadap diri mereka sendiri mengenai masa depannya yang berkaitan dengan masalah pekerjaan di masa depan.

\section{DAFTAR PUSTAKA}

Azwar, S. 2002. Penyusunan Skala Psikologi, Yogyakarta: Pustaka Pelajar

Darhim. 2003. Mengolah Data Melalui SPSS 11.5. Bandung: Universitas Pendidikan Indonesia

Department Agama Republik Indoneisa. 1994. Al-Qur'an dan Terjemahannya, Kitab Suci AlQur'an. Edisi Revisi. Semarang: PT. Kumudesmono

Djamaludin, A. 1989. Teknik Penyususnan Skala Pengukur. Yogyakarta: Pusat Penelitian Kependudukan Universitas Gajah Mada

Freidenberg Lisa. 1995. Psychological Testing Design, Analysis and Use. America : Allyn and Bacon

Gage and Berliner. 1984. Educational Psychology. Boston : Housten Mittlin Company

Hurlock Elizabeth. 1999. Psikologi Perkembangan Suatu Pendekatan Rentang Kehidupan, Edisi Kelima. Jakarta : Erlangga

Mursi, A, H. 2001. SDM Yang Produktif Pendekatan Al-Quran Dan Sains. Jakarta: Gema Insani Press

Nurmi, J, E. 1989. Adolscent Orientation to The Future, Helsinki : Societies Scientiarum Fennica 1991. The Development of Future Orientation In Life-Span Contex

Papalia, Diane, E. 1995. Human Development. New York : McGraw-Hill, Inc

Peri, H. L. 1981. Motivation : Theory and Research. Baltimore, Maryland : Wadsword Publishing Company 
Riyanto, A. 2003. Proses Belajar Mengajar Efektif Di Perguruan Tinggi. Bandung: Yapemdo

Sardiman. 2000. Interaksi dan Motivasi Belajar Mengajar. Jakarta : PT. Raja Gagrafindo Persada

Sarlito.1982. Pengantar Umum Psikologi. Jakarta: Bulan Bintang

Siegel Sidney. 1997. Statistik NonParametrik Untuk Ilmu-Ilmu Sosial. Jakarta :pt. Gramedia Pustaka Utama

Singgih, D. 1983. Pengantar Psikologi. Jakarta : Mutiara

Subini. 1987. Konstruksi dan Analisis Tes. Jakarta : Departement Pendidikan Dan Kebudayaan

Sudjana. 1996. Metoda Statistik. Bandung. : Tarsito

Sugiyono. 2005. Statistik Untuk Penelitian. Edisi baru. Jakarta : Rineke Cipta
Sujanto, A. $1984 . \quad$ Psikologi Perkembangan. Surabaya : Aksara Baru

Sumantri, S dan Suryana, L. 1991.Ringkasan Motif Prestasi Hermans. Bandung : Universitas Padjajaran Bandung

Winkle, W, S. 2004. Psikologi Pengajaran. Edisi Revisi. Jakarta : PT. Grasindo

Winarno, S. 1980. Psikologi Pemuda Dalam Sebuah Pengantar Dalam Pribadi Dan Interaksi Sosialnya. Bandung : Jemmars

Zanden, James, W, V. 1987. Human

Development. New York : McGrew Hill

Companies, Inc. 